\title{
A Cross-Linguistic Perspective on the Expression of Manner
}

\author{
Ana Arregui and Lisa Matthewson \\ University of Massachusetts, Amherst
}

\section{Introduction}

The goal of this paper is to investigate the expression of manner from a crosslinguistic perspective. Our main concern is to investigate whether crosslinguistic evidence supports an analysis of all manner adverbials as predicates over events. We will approach this question by investigating the expression of manner in St'át'imcets (Lillooet Salish), a language unrelated to English.

Davidson (1967) has proposed an analysis of locative and temporal modifiers as predicates over an implicit event argument. An example is given in (1):

a. Mary danced in the kitchen at midnight.

b. ヨe [dancing(Mary, e) \& in (the kitchen, e) \& at (midnight, e)]

Subsequent researchers (a.o. Parsons 1990, Rothstein 1998) have argued that Davidson's proposal should be extended to manner adverbs such as slowly, dangerously, or sadly. An example of Parsons' proposal is given in (2) (the manner adverb is treated as a one-place predicate over events, and the agent is introduced by means of a thematic-role predicate):

a. Mary danced slowly / sadly in the kitchen at midnight.

b. ヨe [dancing(e) \& agent (Mary, e) \& slow (e) / sad (e) \& in (the kitchen, e) \& at (midnight, e)]

However, the claim that all manner adverbials are predicates over events is not uncontroversial. Geuder (2000), for example, has argued that psychological manner adverbials, such as sadly, have readings that involve predication over ordinary individuals instead of events. In this paper we will bring cross-linguistic evidence to bear on this issue.

We will first propose an analysis of manner constructions in St'át'imcets. St'át'imcets is a language that allows locative and temporal modifiers to predicate over events but does not have manner adverbs similar to the English ones. The expression of manner in St'át'imcets is achieved using either subordinate temporal clauses or nominalized constructions. We will propose an analysis of these two strategies couched in the framework of situation semantics [Kratzer 1989]. We will also provide an explanation of why St'át'imcets lacks adverbs similar to the English manner adverbs. We will then investigate the generality of an event-based analysis of manner adverbs. In particular, we will be concerned with psychological manner adverbs. We will show that in St'át'imcets psychological predicates cannot be predicated over events, but can only be predicated over individuals. We will then briefly explore the possibility that this is the case also in English.

The paper is structured as follows. In Section 2 we present the relevant St'át'imcets data and empirical generalizations. In Section 3 we present an analysis of St'át'imcets manner constructions, showing the difference between the two strategies available for expressing manner. In Section 4 we provide an account of why St'át'imcets lacks English-type adverbs. In Section 5 we discuss St'át'imcets data that suggests that psychological predicates are not able to predicate over events, and discuss possible consequences for the analysis of English psychological adverbials. 


\section{The expression of manner in St'át'imcets}

St'át'imcets (Lillooet) is a Northern Interior Salish language spoken in the interior of British Columbia, Canada. It is endangered. All data presented here come from primary field work.

\subsection{The absence of manner adverbs}

St'át'imcets lacks manner adverbs. By this we do not mean simply that St'át'imcets lacks a class of manner adverbs that are morphologically distinct from adjectives. Many languages may fail to overtly distinguish adverbs from adjectives, but still use adjectives in what we would classify as an adverbial construction. A German example is given below:
a. das Auto ist langsam the car is slow 'The car is slow.'
b. Susi fährt langsam
Susi drives slow
'Susi drives slowly.'

St'át'imcets differs from English in a more fundamental way: there are no constructions parallel to the English manner adverb construction. The examples in (4) show that it is not possible to use adjectives inside a VP to modify the description of an event.

$$
\begin{aligned}
& \text { a. *tqálk'-em k'ínk'ent kw-s Mary } \\
& \text { drive-INTR dangerous DET-NOM Mary } \\
& \text { 'Mary drove dangerously.' } \\
& \text { b. *úxwal'-lhkan skenkín } \\
& \text { go.home-lsG.SUBJ slow } \\
& \text { 'I went home slowly.' }
\end{aligned}
$$

The example in (5) shows that the determiner $k u$, which functions as a 'linker' inside various modification structures (see Matthewson 1998), is actually unable to license adjectives appearing inside VP.

$$
\begin{array}{cllll}
\text { * tqálk'-em } & \mathrm{ku} & \text { k'ínk'ent } & \mathrm{kw}-\mathrm{s} & \text { Mary } \\
\text { drive-INTR } & \text { DET } & \text { dangerous } & \text { DET-NOM } & \text { Mary } \\
\text { 'Mary drove dangerously.' } &
\end{array}
$$

In this section we have shown that St'át'imcets has no way of expressing manner by means of a single lexical item inside a VP. In the next section we will discuss the strategies that are available in St'át'imcets.

\subsection{Two strategies for the expression of manner}

St'át'imcets makes available two strategies for expressing manner. The first involves predication over individuals plus a subordinate temporal clause similar to an English when-clause. Examples of this construction are given below:

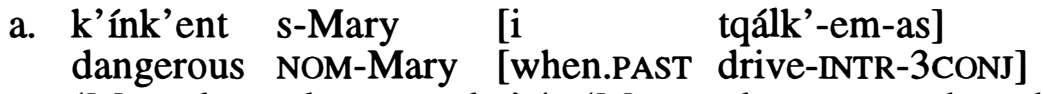

'Mary drove dangerously.' (= 'M. was dangerous when she drove') 
b. pvmp-kán $\quad$ [i $\quad$ q'ílhil-an áti7]
fast-1sG.SUBJ [when. PAST run-1sG.CONJ DEIC]
'I ran quickly.' (= 'I was fast when I ran.')

The main clause in (6a) asserts that Mary was dangerous at some past time, and the subordinate temporal clause restricts that time to a driving time. Similarly, the main clause in (6b) asserts that I was fast at some past time, and the subordinate clause restricts that time to a time at which I was running. Both examples in (6) have temporal clauses headed by the temporal complementizer $i$. The presence of this complementizer restricts the temporal location of the events picked out by the subordinate clause to past times. St'át'imcets does have another complementizer, $l h$, which is not restricted to past times. However, for reasons of space, we will limit our attention in this paper to examples with $i$.

The second strategy available for expressing manner in St'át'imcets involves the nominalization of a clause. A nominalized clause is headed by a determiner $t i-a$ (dialectal variant $t a-a$ ), and the clausal sister to the determiner is headed by a nominalizer $s$-. The sister to $s$ - is a fully inflected clause. Examples of this construction are given below:
a. k'ínk'ent [ti s-tqálk'-em-s-a
s-Mary]
dangerous [DET NOM-drive-INTR-3SG.POSS-DET NOM-Mary]
'Mary drove dangerously.' (= 'Mary's driving was dangerous.')
b. skenkín [ti n-s-xát'-em-a ta sqwém-a] slow [DET 1SG.POSS-NOM-hard-INTR-DET DET mountain-DET] 'I walked up the hill slowly.'
(= 'My walking up the hill was slow.')

In (7a), $k$ 'ink'ent 'dangerous' is predicated of a nominalized clause headed by a determiner ti-a. Similarly, in (7b) skenkin 'slow' is predicated of a nominalized clause headed by ti-a. Two things are worth pointing out at this stage, since we will return to them later. One is that the predicates that we find in (7) can also predicate over ordinary individuals:

$$
\begin{array}{ll}
\text { k'ínk'ent } & \text { s-Mary } \\
\text { dangerous } & \text { NOM-Mary } \\
\text { 'Mary is/was dangerous.' }
\end{array}
$$

The other is that the determiners that head the nominalized clauses are not specific to this construction. They are ordinary determiners that can combine with noun predicates:

$$
\begin{aligned}
& \text { xwesxwís-ana7 ti } \quad \begin{array}{l}
\text { smúlhats-a } \\
\text { smile(REDUP)-ear DET }
\end{array} \text { woman-DET } \\
& \text { 'The woman smiled.' }
\end{aligned}
$$

Ideally, an analysis of (7) should not require making special stipulations about either the predicates or determiners when they appear in this construction. This will be one of the goals of our analysis.

The examples in (10) are presented to show that predication over nominalized clauses does not involve predication over the ordinary individuals that participate in the events:

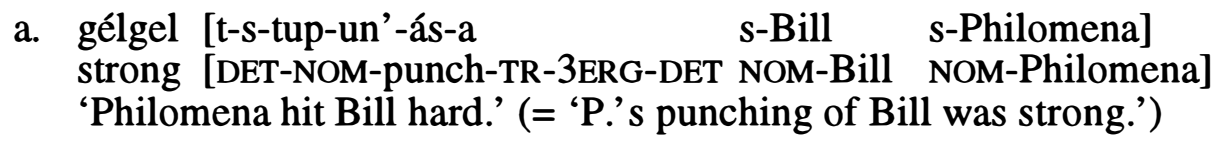




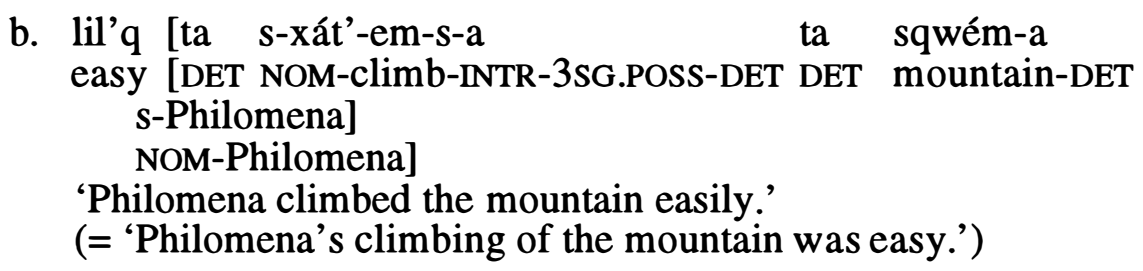

The sentence in (10a) does not assert that Philomena was strong, only that her punching was strong. Similarly, (10b) does not claim that Philomena was easy, only that she climbed easily.

\section{Analysis of the St'át'imcets manner constructions}

In this section we will present an analysis of the two constructions employed to express manner in St'át'imcets.

\subsection{Preliminary assumptions}

Our analysis of St'át'imcets manner constructions is formulated within the framework of Kratzer's (1989) situation semantics. That framework allows us to explain the relation between the interpretation of simple clauses and the interpretation of nominalized clauses in a simple and straightforward manner. Our analysis of nominalized clauses is partly inspired by Zucchi's (1993) proposal for the semantics of nominalized clauses in English, which is also stated within the framework of situation semantics.

Kratzer (1989) proposes a semantic analysis of counterfactual conditionals based on situations. In this paper we will adopt the basic assumptions of that framework. Kratzer distinguishes between two kinds of possible individuals: ordinary individuals and situations. The members of both sets of individuals are partially ordered with respect to each other by means of a part-of relation. The intuition behind the part-of relation between situations is that a situation bears the relation to any other situation that, in an intuitive sense, contains it. Some situations are considered maximal: they are not proper parts of any other situation. Entities that are maximal with respect to the partof relation correspond to what is traditionally thought of as possible worlds. The set of possible worlds therefore, is a subset of the set of possible situations.

In giving a semantic analysis in terms of situations, we will make use of the elements below:

(11) a set of possible situations $S$ (corresponding to the semantic type s) a set of possible individuals I (corresponding to the semantic type e) a partial ordering on the set of situations and individuals $\leq$ the set of maximal elements with respect to the ordering relation, or the set of possible worlds

Sentences will be taken to denote propositions. In the framework developed by Kratzer, propositions are sets of possible situations. So in addition to the elements in (11), we will make use of the power set of $S$ (the set of propositions).

The proposal presented here diverges both from Kratzer's analysis of counterfactuals and from Zucchi's analysis of nominalizations in that, in addition to situations, we will make use of events. We will take events to be a subset of the set of individuals (i.e. a subset of I). We will assume that an event takes place in a situation iff it is part of that situation. An example is given in (12): 


$$
\text { drive }(\mathrm{e})(\text { Mary })(s)=1 \text { iff } \mathrm{e} \text { is an event of Mary driving and } \mathrm{e} \leq \mathrm{s}
$$

Our proposal differs from proposals in the literature that try to reconstruct the notion of event in terms of a primitive notion of situation (e.g. events as minimal situations with certain properties). We will not take a position in the debate as to how events should be defined in terms of situations. As has often been noted, it is notoriously difficult to spell out the individuation conditions on events, and we will set aside this problem here. We will simply treat events as a kind of individual. Further work could allow for a refinement of this proposal.

In dealing with the semantics of St'át'imcets nominalized clauses it will be necessary to spell out the semantics of aspect and tense. To do so we will appeal to a function $\tau$ mapping events to their running times. So, in addition to the set of situations and the set of individuals, we will include as an ingredient in our semantics the set of times $T$ (corresponding to the semantic type $i$ ). Depending on the view adopted with respect to the nature of time, the members of $T$ will or will not be definable in terms of situations or events. We will remain neutral on this point.

Following Partee (1973) and Kratzer (1998a), we adopt a referential analysis of tense. Tenses are taken to be referential expressions, similar to pronouns. They refer to individuals in the domain of times (T). Following Kratzer (1998a), we will assume that aspectual heads map properties of events onto properties of times. Tenses c-command aspectual heads and saturate the time argument corresponding to properties of times, mapping properties of times onto propositions.

St'át'imcets has overt tense and aspect morphology, but such morphology is optional. We will assume that phonologically null tense and aspect heads are present even in cases in which they are not overtly indicated. We will also assume that the default value for aspect is perfective. Evidence supporting this claim comes from aspectual restrictions on present tense interpretations. In St'át'imcets, as in English, only stative eventualities can receive an 'ongoing event' interpretation in the present tense. Bennett and Partee (1978) have argued, with respect to English, that such aspectual restrictions are due to the fact that only stative eventualities (i.e. homogeneous eventualities) can 'fit' within the instantaneous speech time. Their underlying assumption, with respect to English, is that the time of the event must be included within the interval specified by tense. We will incorporate Bennett and Partee's insight about English into our analysis of St'át'imcets by proposing that the default value for aspect is perfective: a perfective operator requires that the running time of the eventuality be included within the temporal interval denoted by tense. In this way we can derive the aspectual restrictions on present tense interpretations. ${ }^{1}$

We will adopt the analysis of aspect and tense presented in Kratzer (1998a). According to that proposal, aspectual heads map properties of events onto properties of times (the interpretation of perfective aspect is given in (13a)). Tenses come in two varieties: deictic and variable tenses (the interpretation of the deictic tenses in St'át'imcets is given in (13b-d), while the interpretation of a phonologically null variable tense is given in (13e)). Variable tenses differ crucially from deictic tenses in that variable tenses can be bound while deictic tenses cannot. The reader is referred to Kratzer (1998a) for discussion and motivation of this proposal.
a. $\left[\left[\varnothing_{\text {perfective }}\right]\right]=\lambda \mathrm{P}_{<\mathrm{e},<\mathrm{s}, \mathrm{t}\rangle>} \lambda \mathrm{t} \lambda \mathrm{s} \exists \mathrm{e}[\mathrm{P}(\mathrm{e})(\mathrm{s}) \& \tau(\mathrm{e}) \subseteq \mathrm{t}]$
b. $[[\mathbf{t u} 7]]=$ a contextually salient past time (abbreviated with $\mathbf{t}_{\text {past }}$ )
c. $\left[\left[\varnothing_{\text {past }}\right]\right]=$ a contextually salient past time (abbreviated with $\mathbf{t}_{\text {past }}$ )
d. $\left[\left[\varnothing_{\text {present }}\right]\right]=a$ contextually salient present time (abbreviated $\mathbf{t}_{\text {pres }}$ )
e. $\left[\left[\varnothing_{i}\right]\right]^{g}=g(i)=t_{i}$ 
Given the assumptions spelled out so far, the LF and interpretation of a simple tensed clause (14a) would be as in (14b) and (14c):

a. tqálk'-em tu7 s-mary

drive-INTR PAST NOM-Mary

'Mary drove'

b. LF

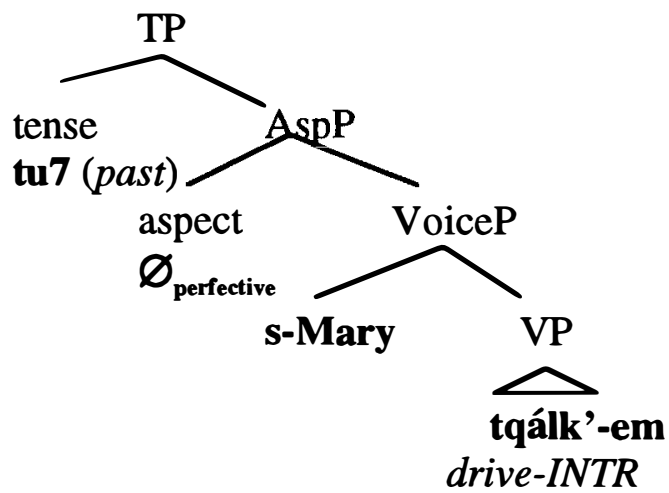

c. $[[\mathrm{TP}]]=\lambda \mathrm{s} \exists \mathrm{e}\left[\operatorname{drive}(\mathrm{e})(\mathrm{s}) \& \operatorname{agent}(\mathrm{Mary})(\mathrm{e})(\mathrm{s}) \& \tau(\mathrm{e}) \subseteq \mathbf{t}_{\text {past }}\right]$

\subsection{Subordinate temporal clauses (i-clauses)}

As we have seen in Section 2.2, subordinate temporal clauses are one of the strategies available for the expression of manner in St'át'imcets. The example in $(6 \mathrm{a})$ is repeated below:

$$
\begin{array}{lll}
\text { k'ínk'ent } & \text { s-Mary } \quad[\mathrm{i} & \text { tqálk'-em-as] } \\
\text { dangerous } & \text { NOM-Mary [when.PAST drive-INTR-3CONJ] } \\
\text { 'Mary drove dangerously.' (= 'Mary was dangerous when she drove') }
\end{array}
$$

We will propose an analysis according to which $i$ binds a temporal variable introduced by tense in the subordinate clause (this analysis predicts that tenses in $i$-clauses are always variable tenses). As mentioned before, the complementizer $i$ indicates that the subordinate clause denotes a property predicated of past times. This restriction to past times will be captured as a presupposition introduced by $i$. The interpretation of $i$ is given below:

$$
[[i]]=\lambda \mathrm{P}_{<\mathrm{i},\langle\mathrm{s}, \gg\rangle} \lambda \mathrm{t}: \mathrm{t} \text { is past }[\mathrm{P}(\mathrm{t})]
$$

Given this proposal, the LF and interpretation of a sentence like (15) will be as in (17): 
a.

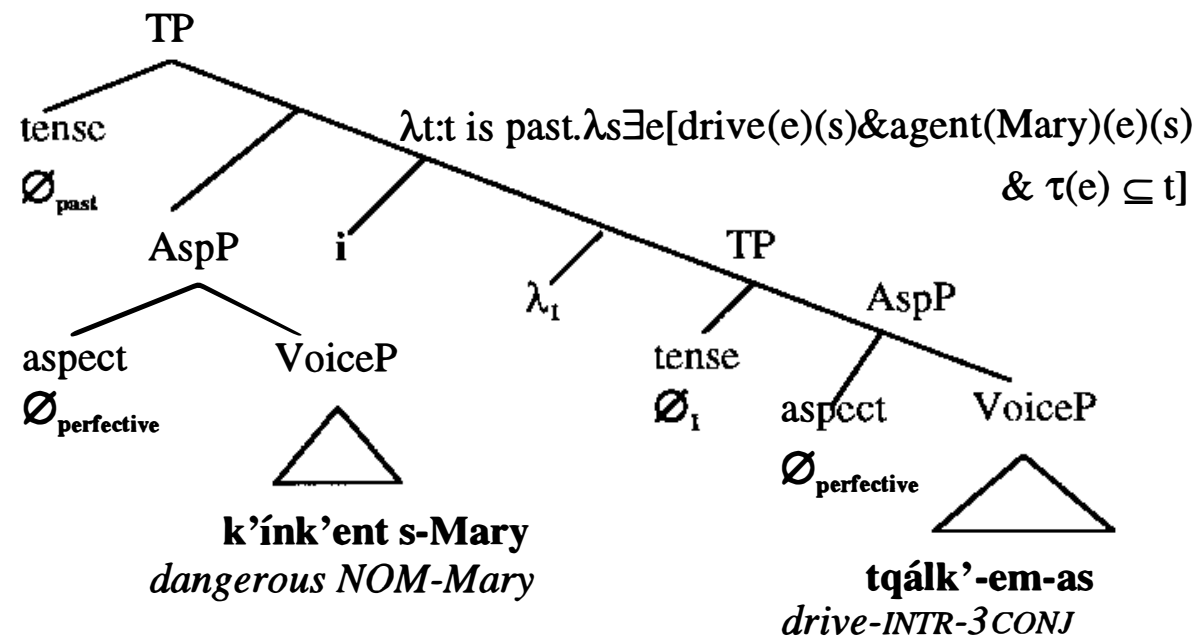

b. $\lambda s \quad \exists e \exists$ ' $\left[\right.$ dangerous (e)(s) \& agent(Mary)(e)(s) \& $\tau(\mathrm{e}) \subseteq \mathbf{t}_{\text {past }}$ \& drive $\left(\mathrm{e}^{\prime}\right)(\mathrm{s}) \&$ agent $($ Mary $\left.)\left(\mathrm{e}^{\prime}\right)(\mathrm{s}) \& \tau\left(\mathrm{e}^{\prime}\right) \subseteq \mathrm{t}_{\text {past }}\right]$

The $i$-clause is interpreted by intersection with the main clause (see Heim and Kratzer's 1998 Predicate Modification Rule). The result is a property of times that contain both events of Mary driving and events of Mary being dangerous. The tense pronoun in TP saturates the temporal argument of this property, resulting in a proposition that corresponds to the set of situations that contain both a past event of Mary driving and a past event of Mary being dangerous. The temporal location of such events is restricted to some contextually salient past time.

According to the analysis proposed here, it is Mary who is asserted to be dangerous, not her driving. Driving in a dangerous manner is certainly one of the ways in which Mary could be dangerous while driving, but it is not the only one. It could be the case that Mary was driving quite cautiously, but was dangerous while driving due to some completely independent factor (e.g. she likes to shoot out of the window while she is driving, and sometimes she hits animals or people). The sentence in (15) can be truthfully uttered in such circumstances, as our analysis predicts.

\subsection{Nominalized clauses}

\subsubsection{The internal structure of nominalized clauses}

As we have seen in Section 2.2, the second strategy available in St'át'imcets to express manner involves the use of nominalized clauses. Example (7a) is repeated below:

k'ínk'ent [ti s-tqálk'-em-s-a s-Mary] dangerous [DET NOM-drive-INTR-3SG.POSS-DET NOM-Mary] 'Mary drove dangerously.' (= 'Mary's driving was dangerous.')

St'át'imcets nominalized constructions do not correspond directly to English gerund constructions (nominalized clauses in English). The St'át'imcets nominalized predicate does not behave like a noun with respect to any of the diagnostics for noun-hood in the language. Moreover, St'át'imcets nominalized clauses allow for the overt presence of both tense and aspect morphology. Examples are given below: 
(19)

a. skenkín [ta s-xát'-em-s-a tu7 s-Mary] slow [DET NOM-climb-INTR-3SG.POSS-DET PAST NOM-Mary] 'Mary climbed slowly.'

b. áma [t-s-wa7 ník'-in-as s-Mary ta ts'úqwaz'-a] good [DET-NOM-PROG cut-TR-3ERG NOM-Mary DET fish-DET] 'Mary was cutting the fish well.'

As in the case of simple clauses, we will assume that tense and aspect heads are present even in the absence of overt morphology.

The nominalized clause in examples like (18) will be assigned the internal structure in (20):

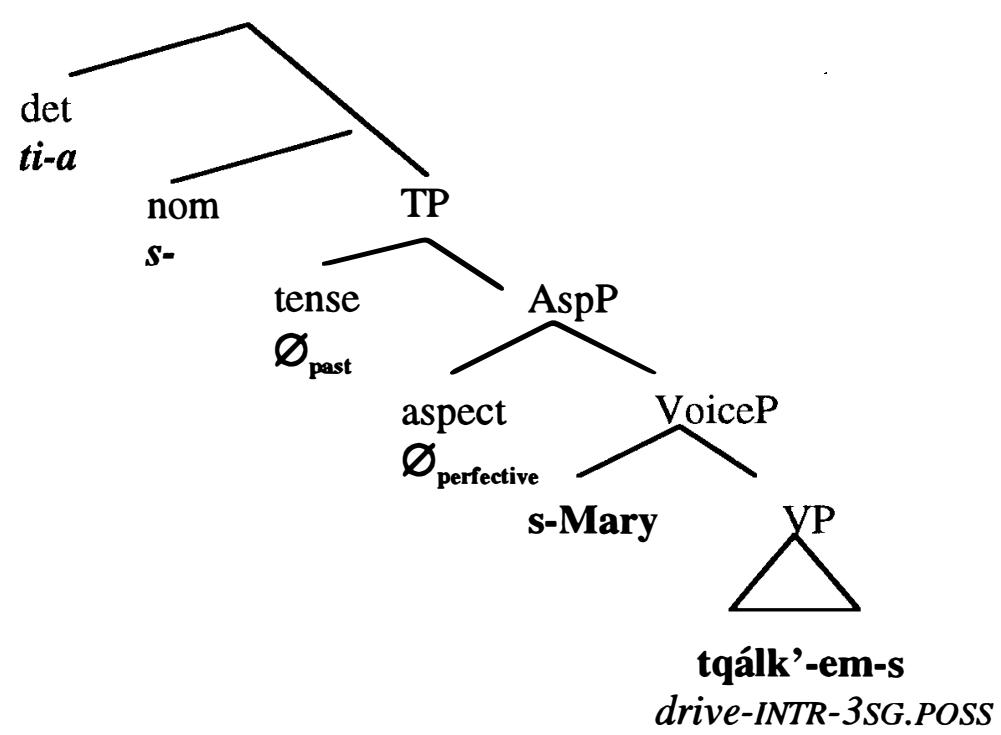

Nominalized clauses in St'át'imcets embed a full TP, and TPs denote propositions. The TP in (20), for example, denotes the proposition specified in (21):

$$
[[\mathbf{T P}]]=\lambda s \exists \mathrm{e}\left[\operatorname{drive}(\mathrm{e})(\mathrm{s}) \& \operatorname{agent}(\operatorname{Mary})(\mathrm{e})(\mathrm{s}) \& \tau(\mathrm{e}) \subseteq \mathbf{t}_{\text {past }}\right]
$$

Part of the challenge of giving an analysis of St'át'imcets nominalized clauses consists in explaining how the meaning of the proposition denoted by the TP contributes to the overall interpretation. We will address this and related issues in the next section.

\subsubsection{Minimal situations in nominalized clauses}

An adequate analysis of St'át'imcets nominalized clauses should explain how the meaning of the entire construction is compositionally derived. This includes accounting both for the meaning contribution of the embedded TP, and for the meaning contribution of the $t i$ - $a$ determiner that heads the nominalized clause. As we have seen in (9) [repeated below], the determiners that head nominalized clause are ordinary determiners that appear in DPs in combination with noun predicates:

$$
\begin{aligned}
& \text { xwesxwís-ana7 ti } \quad \text { smúlhats-a } \\
& \text { smile(REDUP)-ear DET } \\
& \text { 'The woman-DET } \\
& \text { The woman smiled.' }
\end{aligned}
$$

One goal of our analysis is to arrive at a uniform treatment of determiners that 
can account for their interpretation in both constructions.

Matthewson (1999) has investigated the semantics of determiners in combination with noun predicates. She has argued that $t i-a$ determiners in St'át'imcets introduce a variable over choice functions, picking out an individual from the set corresponding to the predicate denoted by the noun [the reader is referred to Matthewson for details and discussion]. The determiner in (22), for example, denotes a contextually salient function that picks out one woman from the set of women, and the sentence then asserts that that woman smiled. Ignoring tense and aspect, a simplified representation of the meaning of (22) is given below:

$$
\text { smiled (f(woman)) }
$$

We will adopt Matthewson's choice-function analysis of determiners and extend it to the cases in which determiners appear in nominalized clauses. To do that we need to explain what the set is that the choice function is operating on in nominalized constructions. Inspired by Zucchi (1993), we would like to propose that nominalized clauses denote minimal situations. We will argue that the choice function determiner $t i$ - $a$ picks out a minimal situation from a set of minimal situations that is the denotation of the clause sister to the determiner, the clause headed by the nominalizer $s$-.

We have proposed that the TP in (20) denotes a proposition: the set of situations that include an event of Mary driving with a running time included in some contextually salient past time (more specifically, the characteristic function of that set). The set corresponding to the proposition contains all situations that include such a driving event, both minimal and non-minimal (it will, for example, include the maximal situations that contain such an event, entire worlds). Clearly the choice function determiner does not operate on such a set (it cannot pick out an entire world). It operates on the subset of that set made up of minimal situations. We propose that the nominalizer $s$ - is responsible for trimming away the non-minimal situations in the TP. $s$ combines with a proposition and the result is the subset of minimal situations within that proposition. The interpretation we propose for $s$ - is given below:

$$
[[\mathrm{s}]]=\lambda \mathrm{P}<\mathrm{s,t}>\lambda s\left[\mathrm { P } ( \mathrm { s } ) \& \forall \mathrm { s } ^ { \prime } \left[\left[\mathrm{P}\left(\mathrm{s}^{\prime}\right) \& \mathrm{~s}^{\prime} \leq \mathrm{s}\right] \rightarrow \mathrm{s}^{\prime}=\mathrm{s}^{2}\right.\right.
$$

(abbreviated as: $\lambda P \lambda s[P(s) \& \min (s)])$ [Heim 1990, von Fintel 1994]

Given this semantics for $s$-, the denotation of the clause sister to the determiner in (20) will be as in (25):

$$
\begin{aligned}
& {\left[\left[s \varnothing_{\text {past }} \varnothing_{\text {perfective }}[\text { Voicep tqálk'-ems sMary] }]\right]=\right.} \\
& \lambda s \quad \exists \mathrm{e}\left[\text { drive(e)(s) \& agent (Mary)(e)(s) \& } \tau(\mathrm{e}) \subseteq \mathrm{t}_{\text {past }} \& \min (\mathrm{s})\right]
\end{aligned}
$$

According to (25), the clause headed by $s$ - denotes the set of minimal situations that contain an event of Mary driving. What do such situations look like? How are they made up? According to the definition in (24), minimal situations that contain a driving event by Mary will have no proper subparts that also contain that event. This is because they have no parts that are irrelevant to the event. In fact, the minimal situations that contain such events will turn out to be indistinguishable from the events themselves. When we talk about a minimal situation containing an event we are, in a sense, referring to one individual twice, once under the guise of an event, and once as a situation. Given this view of situations and events, the set of minimal situations containing certain events turns out to be identical to the set of events itself.

Under the analysis proposed above, the clause headed by $s$ - and the VP in (20) can both pick out a set of events in a world. They do not, however, pick out the same set. The VP picks out all the driving events. The clause headed 
by $s$ - picks out a subset of the driving events: it picks out those driving events that are events of driving by Mary that have a running time that is included in the contextually salient past time.

Since the choice function determiner combines with a clause that denotes a set of minimal situations that contain an event of the relevant kind, it will, in fact, pick out one of those events. The denotation of the nominalized clause will then be a contextually salient event (i.e. an event selected by a contextually salient choice function). In an example like (18) the nominalized clause picks out a contextually salient event/minimal situation of Mary driving, and the sentence then asserts that that event was dangerous.

Matthewson notes that the choice function determiner $t i$ - $a$ carries existence entailments: DPs headed by $t i-a$ refer to individuals that actually exist [Matthewson 1998, 1999]. There is a parallel in the domain of nominalized clauses, as nominalized clauses are factive and are taken to refer to events that have actually taken place. This could be captured if it were the case that the choice-function determiner can only pick out an actual-world minimal situation. Working out such restrictions, however, remains a matter for future research (cf. Zucchi, who also argues that nominalized clauses (in English) presuppose that an event of the relevant kind has occurred).

\subsubsection{Predicating over events}

According to the analysis spelled out above, clauses headed by the nominalizer $s$-denote (the characteristic functions of ) sets of situations that are also events. This means that such clauses are ambiguous as to their semantic type. Viewed as sets of situations, they would be classified as of type $<s, t>$. Viewed as sets of events, they would be classified as of type $<e, t>$ (recall that events are a subset of the set of individuals). That is, clauses headed by $s$ - can be characterized as denoting predicates of individuals. According to Matthewson, choice function determiners map such predicates onto a contextually salient individual. The result is that a nominalized clause denotes an individual (type e).

Given their semantic type, nominalized clauses can combine with predicates of individuals. We suggest that that is indeed what happens in examples like (18). The predicate k'ink'ent 'dangerous' can be predicated of ordinary individuals (as in (8), repeated as (26)), or of events (as in (18), repeated as (27)):

$$
\begin{aligned}
& \text { k'ínk'ent } \quad \text { s-Mary } \\
& \text { dangerous } \\
& \text { 'MOM-Mary is/was dangerous.' }
\end{aligned}
$$

k'ínk'ent [ti s-tqálk'-em-s-a s-Mary]

dangerous [DET NOM-drive-INTR-3SG.POSS-DET NOM-Mary]

'Mary drove dangerously.' (= 'Mary's driving was dangerous.')

It is possible to capture the interpretation of k'ink'ent (dangerous) in both cases by treating it as a predicate of individuals. In sentences like (27) it combines with a nominalized clause. The LF of (27) will be as in (28a), and its interpretation as in (28b): 
(28)

a.

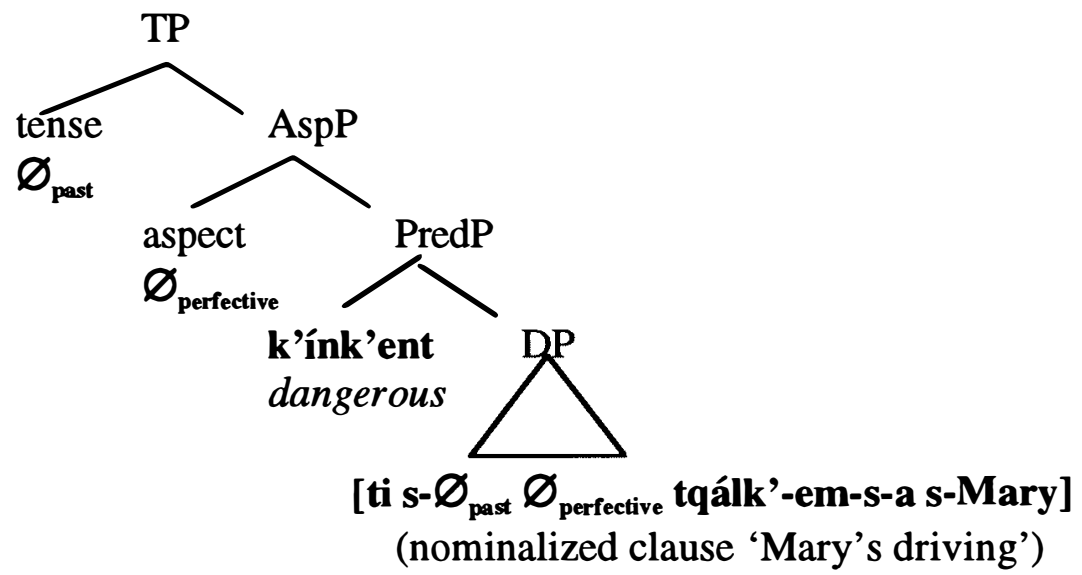

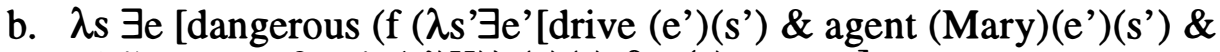
$\left.\left.\left.\left.\left.\tau\left(\mathrm{e}^{\prime}\right) \subseteq \mathbf{t}_{\text {past }} \& \min \left(\mathrm{s}^{\prime}\right)\right]\right]\right)\right)(\mathrm{e})(\mathrm{s}) \& \tau(\mathrm{e}) \subseteq \mathbf{t}_{\text {past }}\right]$

\subsubsection{Summary}

In this section we have given an analysis of the semantics of St'at'imcets nominalized constructions. We have argued that in this construction a choice function determiner picks out a minimal situation from a set. Since such a situation will be extensionally equivalent to an event, nominalized clauses can be taken to denote contextually salient events. In the framework we have adopted, events are a kind of individual. Predicates that can predicate over individuals will also (sometimes) be able to predicate over events, and in this way a manner interpretation will be achieved.

\section{Why St'át'imcets lacks manner adverbs}

Having provided an analysis of the St'át'imcets manner constructions, we now turn to the question of why St'át'imcets lacks constructions like the English manner adverb construction. As we discussed in Section 1, many researchers assume that the English construction involves predication over an event argument. An example is given below:

(29) a. Mary drove slowly / dangerously / sadly.

b. $\exists$ e [driving (e) \& agent (Mary, e) \& $\underline{\operatorname{slow}}(\mathrm{e}) / \underline{\text { dangerous }}(\mathrm{e}) / \underline{\operatorname{sad}}(\mathrm{e})$ ]

It could be thought that the reason that St'át'imcets lacks logical forms like (29b) is that it lacks an event argument altogether. We will show in the next section that such an explanation would be wrong and that there is evidence that St'át'imcets does have an event argument.

\subsection{Locative and temporal modifiers in St'át'imcets}

St'át'imcets possesses locative and temporal modifiers parallel to those originally used by Davidson to motivate an event analysis for English. Examples are given in (30):

a. k'wezús-em s-Mary l-ti lep'-cál-tn-a work- INTR NOM-Mary in-DET dig-INTR-INSTR-DET 'Mary worked in the garden.' [locative modifier] 


\section{b. t'ak t'u7 xelh lhél-na lhwál'tsten-a t'ánam'ten go just cold from-DET October-DET month 'It's got cold since October.' [temporal modifier]}

Davidson argued that an event analysis is needed to straightforwardly capture the entailment relations holding between sentences containing modifiers of this type and sentences lacking them. An example of the entailment relations is given below [(32) is entailed by (31)]:

a. Mary danced in the bathroom.

b. ヨe [dancing (e) \& agent (Mary, e) \& in (the bathroom, e)]

a. Mary danced.

b. ヨe [dancing (e) \& agent (Mary, e)]

The entailment facts motivating Davidson's proposal are found also in St'át' imcets. The sentence in (30a), for example, entails the sentence in (33):

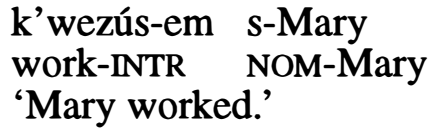

Given that the entailment facts are the same in St'át'imcets as in English, equal support for an event-based analysis of locative and temporal modifiers is to be found in both languages. Such an analysis is illustrated below for St'át' imcets, where (34) is the LF of (30a):

$\lambda s \exists \mathrm{e}[$ work (e)(s) \& agent (Mary)(e)(s)

$\&$ in (the garden $\left.)(\mathrm{e})(\mathrm{s}) \& \tau(\mathrm{e}) \subseteq \mathbf{t}_{\text {pres }}\right]$

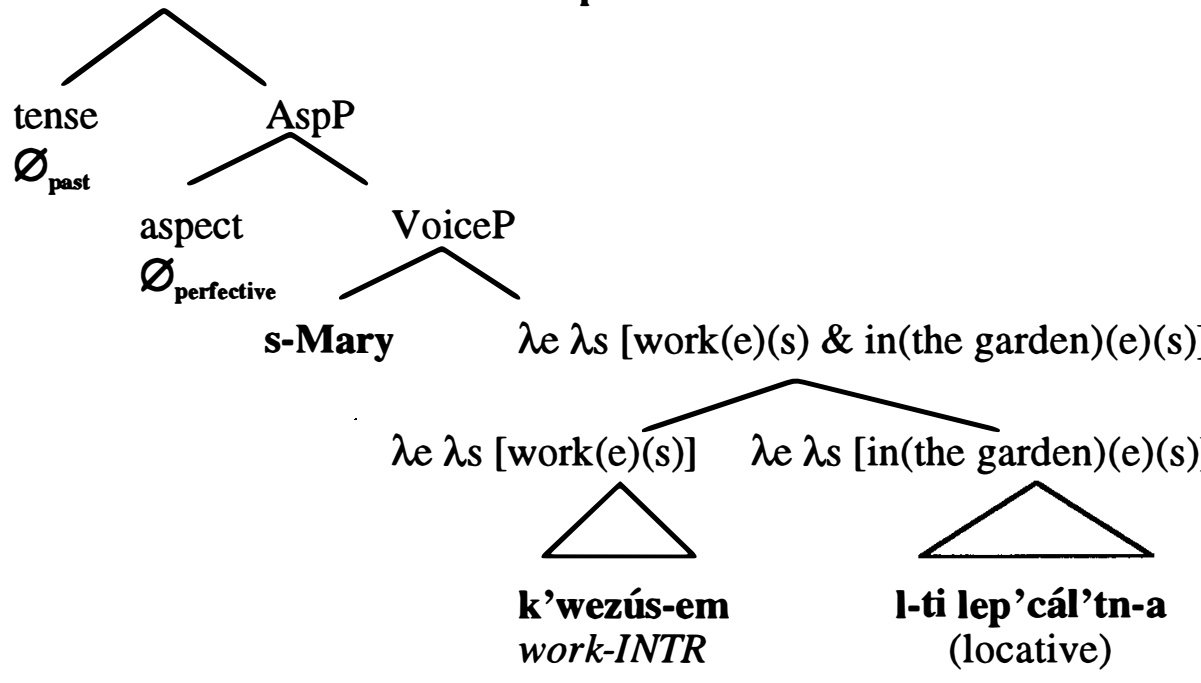

The data presented in this section suggest that the evidence for an implicit event argument is as good in St'át'imcets as in English. In principle nothing rules out predication over an implicit event argument in St'át'imcets. The difference between St'át'imcets and English with respect to manner adverb constructions must come from another source.

\subsection{The solution}

We propose that St'át'imcets lacks manner adverbs because it lacks lexical items with the right argument-structure properties. Following Matthewson and 
Davis (1995), Davis (2000), we claim that St'át'imcets possesses only a twoway distinction in lexical categories: nouns vs. everything else. The difference is that while nouns may appear in the syntax as bare predicates, without projecting to tense, non-nouns necessarily project clausal structure. ${ }^{3}$

Given the claim above, it follows that a predicate like skenkin 'dangerous' will always appear with its own tense and external argument. It is impossible for a lexical item of this type to predicate directly over the event argument: a type mismatch would ensue. This is illustrated below:

a. *tqálk'-em k'ínk'ent kw-s Mary drive-INTR dangerous DET-NOM Mary 'Mary drove dangerously.'

b.

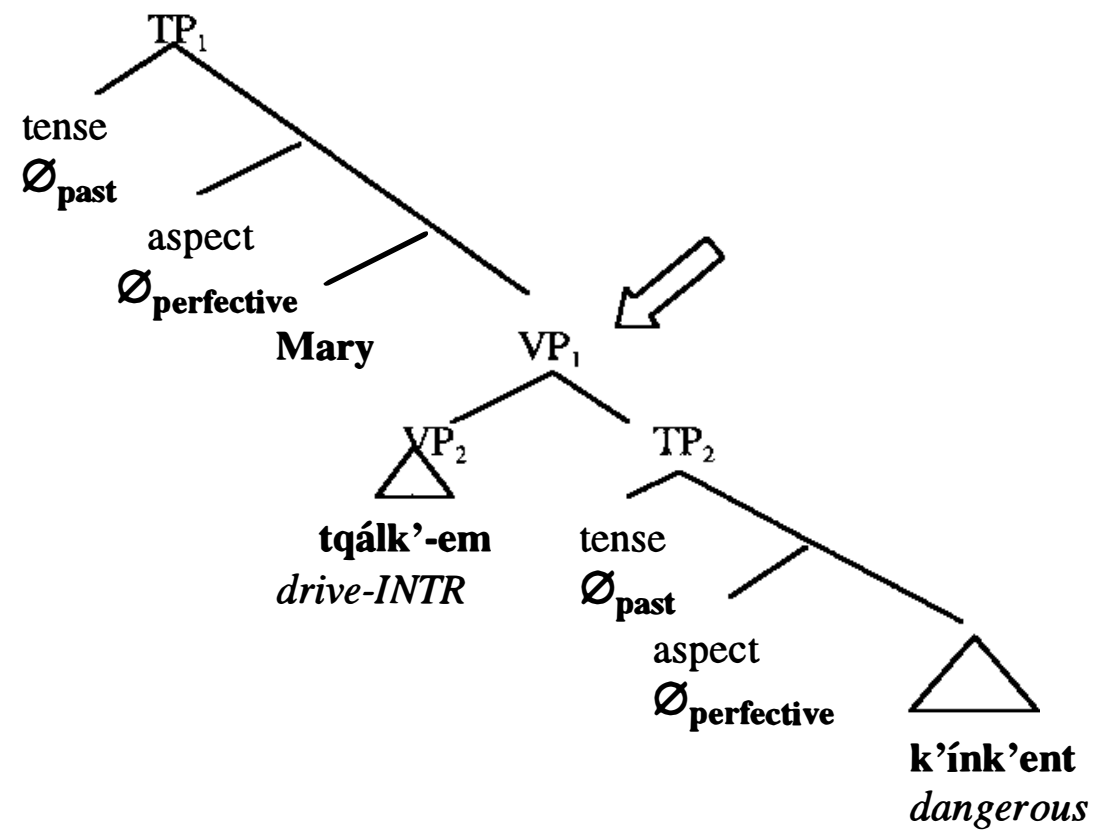

There is a type mismatch at the $\mathrm{VP}_{1}$ node: $\mathrm{VP}_{2}$ is a property of events and $\mathrm{TP}_{2}$ is a proposition.

The explanation given here of the ungrammaticality of (35a) is similar to the explanation that would be given of the ungrammaticality of (36):

a. *Mary drove was dangerous.

b. *Mary drove scared me.

In English, two verbs cannot predicate over the same event because each verb must have its own functional structure (i.e. it must project to Tense). The difference between St'át'imcets and English is that English has a separate category of Adjectives which do not have to project to Tense.

The claim that the inability of verbs in English to function as adverbs is due to a tense requirement is found also in observations made by Rothstein (1983:148):

There are no verbal adjuncts ... This systematic gap can be explained in the following way ... adjunct predicates are always uninflected. Prepositional adjectival and nominal heads are not morphologically inflected and therefore there is no problem with their being used as adjuncts. Verbs, unlike these other categories, have a morphological 'slot' for inflection, and require an inflectional affix of some kind in order to be morphologically well formed. 
The proposal made here also bears some similarity to claims made by Baker (in prep.). In his discussion of the defining properties of adjectives and verbs, Baker argues that

only verbs have the power to take a specifier, which is normally thetamarked as a theme or agent ... The distinctive property of a verb is that it has a theta role to discharge; if that theta role is not properly assigned, the structure will be ruled out by the (ordinary) theta criterion.

While there are many differences in detail between Baker's analysis and ours, it seems that there is a common prediction to both: in a language which lacks a category of adjectives separate to verbs, adverbs will also be absent.

\subsection{A consequence for locative and temporal modifiers}

The analysis presented above makes a prediction about locative and temporal modifiers in St'át'imcets. In Section 4.1 we analyzed such modifiers as event predicates inside the VP. Given our discussion in Section 4.2, the prediction is that such modifiers need not project Tense (otherwise they too would lead to a type mismatch). This prediction is upheld. The examples in (37) show that locative and temporal modifiers are unable to function as main predicates (in this they differ from all other XP categories such as AP, NP or VP):

$$
\begin{array}{clll}
\text { a. *l-ta tsítcw-a } & \text { kw-s } & \text { Bucky } \\
\text { in-DET house-DET } & \text { DET-NOM Bucky } \\
\text { 'Bucky is in the house.' } &
\end{array}
$$
b. *pináni7 ku sútik ta t'ép-a máqa7 then DET winter DET deep-DET snow 'The deep snow was that winter.

Sentences like (37a) become grammatical if a locative predicate $w a 7$ 'to be in a location' is added. In (38), wa7 functions as the main predicate of the sentence, and it takes the locative PP as one of its arguments:

$$
\begin{array}{llll}
\text { wa7 l-ta tsítcw-a } & \text { kw-s } & \text { Bucky } \\
\text { loc in-DET house-DET } & \text { DET-NOM } & \text { Bucky } \\
\text { 'Bucky is in the house.' } &
\end{array}
$$

Summarizing the results of this section, we have argued that only lexical items that need not project their own clausal structure can be added as predicates of events within the VP. The absence of manner adverbs in St'át'imcets is due to the restricted categorial system of the language.

\section{Psychological adverbs}

As was mentioned in Section 1, objections have been raised to the claim that all manner adverbs are predicates over events. Geuder (2000), for example, has argued that psychological manner adverbs predicate over ordinary individuals in some interpretations. In this section we will discuss data from St'át'imcets that suggest that psychological manner adverbs actually never predicate over events, and then we will discuss the consequences of adopting this view for English. 


\subsection{Psychological predicates in St'át'imcets}

According to the analysis proposed in Section 3, nominalized clauses in St'át'imcets denote a single salient event. In examples like (18) [repeated below], a nominalized clause functions as the subject of a predicate: the sentence asserts that Mary's driving was dangerous (see (28) above).

$$
\begin{aligned}
& \text { k'ínk'ent [ti s-tqálk'-em-s-a s-Mary] } \\
& \text { dangerous [DET NOM-drive-INTR-3SG.POSS-DET NOM-Mary] } \\
& \text { 'Mary drove dangerously.' (= 'Mary's driving was dangerous.') }
\end{aligned}
$$

Our conclusion was that with nominalized clause subjects, the predicate is predicated over the event denoted by the clause. In this way a 'manner' interpretation is obtained.

Interestingly, not all predicates can combine with a nominalized clause. Some examples of ungrammatical attempts are given below:

$$
\begin{aligned}
& \text { a. *qlil [ta s-we7áw-s-a s-Mary] } \\
& \text { angry [DET NOM-holler-3sG.POss-DET NOM-Mary] } \\
& \text { 'Mary shouted angrily.' (= 'Mary's shouting was angry.') }
\end{aligned}
$$

Consultant's comment: "Bad. You're not saying who got mad because she hollered."

$$
\begin{aligned}
& \text { b. *qwenúxw-alhts'a7 [ta s-mátq-s-a káti7 s-Mary] } \\
& \text { sick-inside [DET NOM-walk-3sG.POSS-DET DEIC NOM-M.] } \\
& \text { 'Mary walked around sadly.' (= 'Mary's walking around was sad.') } \\
& \text { c. *kwezín'cwem [ta nk'talus-mín-ts-as-a s-Mary] } \\
& \text { jealous [DET (NOM)-stare-APPL-1SG.OBJ-3ERG-DET NOM-M.] } \\
& \text { 'Mary stared at me jealously.' (= 'M.'s staring at me was jealous.') }
\end{aligned}
$$

The ungrammaticality of examples like (40) suggests that psychological manner adverbs do not predicate over events. We suggest that such predicates only predicate over ordinary individuals. This predicts that such predicates will be acceptable in subordinate $i$-clauses, and the prediction is borne out:
a. qlil kw-s Mary [i we7áw-as] angry DET-NOM Mary [when.PAST holler-3CONJ]
'Mary shouted angrily.' (= 'Mary was angry when she shouted.')
b. qwenúxw-alhts'a7 s-Mary [i mátq-as káti7] sick-inside NOM-Mary [when.PAST walk-3CONJ DEIC] 'Mary walked around sadly.' (= 'Mary was sad when she walked around.')

When consultants are asked to translate English sentences containing depictives, the same subordinate clause construction is used, as illustrated in (42). This suggests that whatever the distinction is between English adverbial and depictive constructions, the distinction is neutralized in St'át'imcets :
qlil kw-s Philomena [i t'íq-as]
angry DET-NOM Philomena [when.PAST arrive-3CONJ]
'Philomena arrived angry.' (= 'P. was angry when she arrived.')

Having argued that psychological predicates in St'át'imcets always predicate over ordinary individuals, the prediction now is that it will be contradictory to deny that the relevant emotional state holds of the individual. 
And this prediction is borne out:

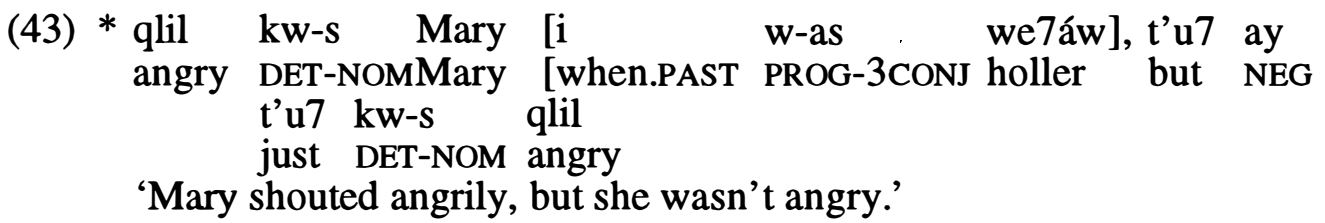

We claim that in St'át'imcets psychological state predicates are always predicated over ordinary individuals, and never over events. We will briefly investigate the consequences of a similar hypothesis for English in the next section.

\subsection{Subject depictives and psychological adverbs in English}

The contrast exemplified in (44) appears problematic for the claim that in English psychological predicates can only predicate over ordinary individuals, and not over events.

a. John left the room sad.

b. John left the room sadly.

A fully generalized event-predicate analysis of adverbs can easily capture the difference between (44a) and (44b) by claiming that the adverb, and not the depictive, predicates over the event argument, as illustrated in (45):
a. ヨe [leave(e) \& Theme(John, e) \& sad(John)]
b. $\exists$ e [leave(e) \& Theme(John, e) \& sad(e)]

However, the availability of logical forms like (45b) in English makes it totally mysterious why psychological predicates cannot predicate over events in St'át'imcets nominalized clauses. We would like to suggest that (45) may not be the correct analysis of the contrast in (44). Instead, we would like to differentiate between sad and sadly in terms of evidentiality. We claim that both sad and sadly predicate over ordinary individuals. The difference is that sad asserts that an individual is actually sad, while sadly only asserts that an individual appears to be sad. A proposal along these lines would capture the contrast in (44), and would also be able to explain why examples like (46) are felicitous (and not contradictory):

a. John walked sadly off the stage, but he wasn't sad.

b. Although Jan drove the car drunkenly, she wasn't drunk.

c. Although Jan drove the car drunk, she didn't drive drunkenly. [(46c) is from Déchaine 1993]

One obvious question raised by this proposal is how the evidential meaning we have assigned to -ly can be reconciled with the other nonevidential uses of this suffix. Some examples are given in (47):

a. Fortunately / happily / luckily, it didn't rain.
b. Frankly / honestly, I don't give a damn.

We are not able to provide a thorough analysis of the -ly suffix in this paper. It could be the case that there is more than one -ly suffix in English. Or that $-l y$ itself is semantically vacuous, and that in English evidentiality is expressed by means of a phonologically null morpheme. The topic remains a matter for future research. 


\subsection{Back to St'át'imcets: The evidential reading}

According to the proposal sketched in Section 5.2, adverbs like sadly are actually predicates over ordinary individuals. They differ from sad in terms of evidentiality, not in terms of argument structure. If the evidential sadlyreading is obtained by predicating over ordinary individuals, we expect to find an equivalent reading in St'át'imcets. In this section we will discuss how that reading arises.

St'át'imcets possesses a set of clitics which encode notions like 'evidential', 'quotative', 'surmise'. These clitics are obligatory. If they are absent, the speaker is assumed to have direct knowledge of what is being reported. This is illustrated in (48):
a. wa7 qwenúxw-alhts'a7 kw-s Harry PROG sick-inside 'Harry is sad.'
DET-NOM Harry
b. wa7-as-an' qwenúxw-alhts'a7 kw-s Harry be-3CONJ-EVID sick-inside DET-NOM Harry 'Harry seems sad.'

The sentence in (48a) is judged to be appropriate only if the speaker really knows that Harry is sad (i.e., Harry must have told the speaker that he is sad). If it just looks like Harry is sad (e.g., he has a sad expression on his face), then (48a) is inappropriate, and an evidential construction such as in (48b) must be used.

Examples like the ones in (48) suggest that the sadly-reading should be expressed in St'át'imcets using the evidential markers that are independently utilized in the language. The examples in (49) show that this is indeed the case. When consultants are asked to express that an action was performed in a sad manner, without the individual necessarily being sad, they volunteer the following overtly evidential constructions:
a. qwenuxw-alhts'á7-as-a s-Mary [i wá7-as káti7 matq] sick-inside-3CONJ-DET NOM-M. [when PROG-3CNJ DEIC walk] 'Mary seemed sad when she was walking around.'
b. qwenúxw-alhts'á7-as-a k'a [i w-as matq s-Jason] sick-inside-3CONJ-DET EVID [when PROG-3CONJ walk NOM-J.] 'Jason seemed sad when he was walking around.'

\section{Conclusion}

St'át'imcets is a language that lacks manner adverbs similar to the English ones. Two constructions are available to express manner: subordinate temporal clauses and nominalized clauses. In this paper we have proposed an analysis of these constructions, as well as an explanation of why St'át'imcets lacks English-type adverbs.

Many researchers working within neo-Davidsonian frameworks have proposed to analyze manner adverbs as predicates over events. However, the generality of this treatment has been questioned in the literature. It has been suggested that psychological adverbs do not necessarily predicate over events. We have argued that in St'át'imcets psychological predicates actually never predicate over events. And we have suggested that this view could be adopted for English too. 


\section{Endnotes}

*We are very grateful to Beverley Frank, Gertrude Ned, Laura Thevarge and Rose Whitley for sharing their knowledge of St'át'imcets. We are also very grateful to Henry Davis for helping with data collection, and to Henry Davis, Irene Heim and Angelika Kratzer for a lot of helpful discussion and feedback. Thanks also to the participants of Ling 720 at the University of Massachusetts, Amherst and to audiences at McGill University, UCLA, CUNY and SULA for useful comments. Fieldwork was supported in part by SSHRCC grant \#41095-1519.

${ }^{1}$ Thanks to Mike Terry for very helpful discussions about aspect in English.

2 This definition of 'minimal situation' gives incorrect results for cases in which the eventualities are states or activities (see von Fintel (1995)). We will adopt it here as a simplification . The reader is referred to Kratzer (1998b:178) for a more accurate characterization in terms of 'exemplification'.

${ }^{3}$ For reasons of space, we will not discuss this issue here. The reader is referred to the cited work for arguments, as well as Jelinek 1995, Jelinek and Demers 1994, Demirdache and Matthewson 1995.

\section{References}

Baker, M. in prep. Categories and Categorial Systems. Ms., Rutgers University.

Bennett, M. and B. Partee 1978. Toward a Logic of Tense and Aspect in English. Indiana University Linguistics Club.

Davidson, D. 1967. The logical form of action sentences. Reprinted in D. Davidson (1980). Essays on Actions and Events. Oxford University Press, Oxford. 105-148.

Davis, H. 2000. Remarks on Nouns and Nominalization in Salish. Ms., University of British Columbia.

Déchaine, R.M. 1993. Predicates Across Categories: Towards a CategoryNeutral Syntax. Ph.D. dissertation, University of Massachusetts, Amherst.

Demirdache, H. and L. Matthewson 1995. On the universality of syntactic categories. Proceedings of NELS 25: 79-93.

Fintel, K. von 1994. Restrictions on Quantifier Domains. Ph.D. dissertation, University of Massachusetts, Amherst.

Fintel, K. von 1995. A minimal theory of adverbial quantification, Ms., MIT.

Geuder, W. 2000. Oriented adverbs. Ph.D. dissertation, Universität Tübingen.

Heim, I. 1990. E-type Pronouns and donkey-anaphora, Linguistics and Philosophy 13: 137-177.

Heim, I. and A. Kratzer 1998. Semantics in Generative Grammar. Oxford: Blackwell.

Jelinek, E. 1995. Quantification in Straits Salish. In E. Bach, E. Jelinek, A. Kratzer and B. Partee (eds.), Quantification in Natural Languages, 487540. Dordrecht: Kluwer.

Jelinek, E. and R. Demers 1994. Predicates and pronominal arguments in Straits Salish. Language 70:697-736.

Kratzer, A 1989. An investigation of the lumps of thought. Linguistics and Philosophy 12: 607-653.

Kratzer, A. 1998a. More structural analogies between tenses and pronouns. Proceedings of SALT VIII.

Kratzer, A. 1998b. Scope or pseudoscope? Are there wide-scope indefinites? in Susan Rothstein (ed.), Events in grammar, Dordrecht: Kluwer. 163196.

Matthewson, L. 1998. Determiner Systems and Quantificational Strategies: 
Evidence from Salish. The Hague: Holland Academic Graphics.

Matthewson, L. 1999. On the interpretation of wide scope indefinites. Natural Language Semantics 7:79-134.

Matthewson, L. and H. Davis 1995. The structure of DP in St'át'imcets (Lillooet Salish). Papers for the 30th International Conference on Salish and Neighboring Languages, 54-68. Victoria: University of Victoria.

Parsons, T. 1990. Events in the Semantics of English. Cambridge, MA: MIT Press.

Partee, B. 1973. Some structural analogies between tenses and pronouns in English. The Journal of Philosophy 70: 601-609.

Rothstein, S. 1983. The syntactic forms of predication. Ph.D. diss, MIT.

Rothstein, S. 1998. In S. Rothstein (ed.), Events in Grammar. Dordrecht: Kluwer. 1-11.

Zucchi, A. 1993. The Language of Propositions and Events. Dordrecht: Kluwer Academic Publishers. 